〈解説〉

\title{
環境中の化学物質に関するデータベースシステム 拉よび検索システムの開発
}

\author{
安 原 昭 夫*, \\ Akio YASUHARA
}

\section{1.はじめに}

今日, 科学技術に関係した情報は, 膨大な量が日々 生産されているが，有効に利用されないで埋もれてい く量もまた増光ている。特に環境分野のような境界領 域に揖いては情報源が多岐にわたっているため，情報 が分散してしまい，研究を効率的に進める上で大きな 障害となっている。文献情報等についてのデータベー ス拉よび検索システムはすでに各種のものが開発され 実用化されているが，化学物質という観点から各種の データを取りいれた大規模データベースシステムは, 現在 Chemical Information System(CIS) 以外に適当 なものは見当らない1,2)。このような現状を踏ま兄て, 我 国に拀いても科学技術に関する研究をより効果的に推 進させるために，これらの多岐にわたる各種の情報を 体系的に収集, 整理して迅速かつ容易に検索できる データベースシステムの実現が望まれている。科学技 術庁に拈いて，1981年から 5 ヶ年計画で「ネットワー ク共用による化合物情報等の利用高度化に関する研 究」が始まっている。そこでは各省庁の参加の下で, 化学物質に関するデータベースをそれぞれの専門分野 ごとに構築し，ホストコンピューターを介して，ュー ザーが手軽に利用できる共用ネットワークシステムの 完成を目的としている。研究は緒についたばかりであ るが，その概要を図1に示した。内容は大きく2つに 分けられ, ネットワーク共用分科会は, 各データベー スをオンラインで結び，ネットワーク共用を実現する ための通信技術や情報管理技術の開発を受け持ってい る。一方, 化合物データベース分科会では, 10 種類の データベースの構築と検索システムの開発を目ざして いる。完成した暁には, 端末から電話回線を利用して
特定の化学物質の各種のデータが入手できるだけでな く, 未知物質の同定も可能となる。この分科会の中で, 化合物辞書データベースは他のデータベースとは異っ た立場にあり，各々のデータベース中の化合物を共通 の番号で相互に関連づけたり, 構造式を表示する役目 を荷なっている。著者らはこのプロジェクト研究の中 の環境データベース作業分科会を担当している。その 内容は環境化学物質データベースシステムとマススペ クトルデータベースシステムの設計であり, 検索シス テムも含めて以下にそれらの概要を紹介する。な招, 本サブシステムは国立公害研究所のコンピューターを ホストとして地方公害研究所をネットワークで結ぶオ ンラインシステムとしての利用も可能である。

\section{2. 環境化学物質データベースシステム}

このデータベースシステムは環境中に存在する無数 の化学物質の中で有害と思われるものを選び出して, 物性, 分析法, 環境中での測定值, 毒性などの情報を 整理し，多くのユーザーに供することを目的としてい る。当面は対象化学物質として, 環境庁が作成したプ ライオリティーリストに収録されている約 2,000 余り の化学物質に限定しているが, 採来, 各機関からデー 夕の提供が行なわ机るよらになれば, それらも収納し ていく予定である。現在, データが入力されている化 学物質の数は約 400 余りにすぎない。入力データの内容 について以下に説明する。

(1)物質同定番号

4 種類あり, このシステム自体の整理番号（入力 順), プライオリティーリストの分類番号, 国際的 に共通な CAS 登録番号, それに科学技術庁のオ

* 国立公害研究所計測技術部 $=305$ 茨城県筑波郡谷田部町小野川16-2, Division of Chemistry and Physics, National Institute for Environmental Studies, 16-2, Onogawa, Yatabe-machi, Tsukuba-gun, Ibaraki 305 Japan 


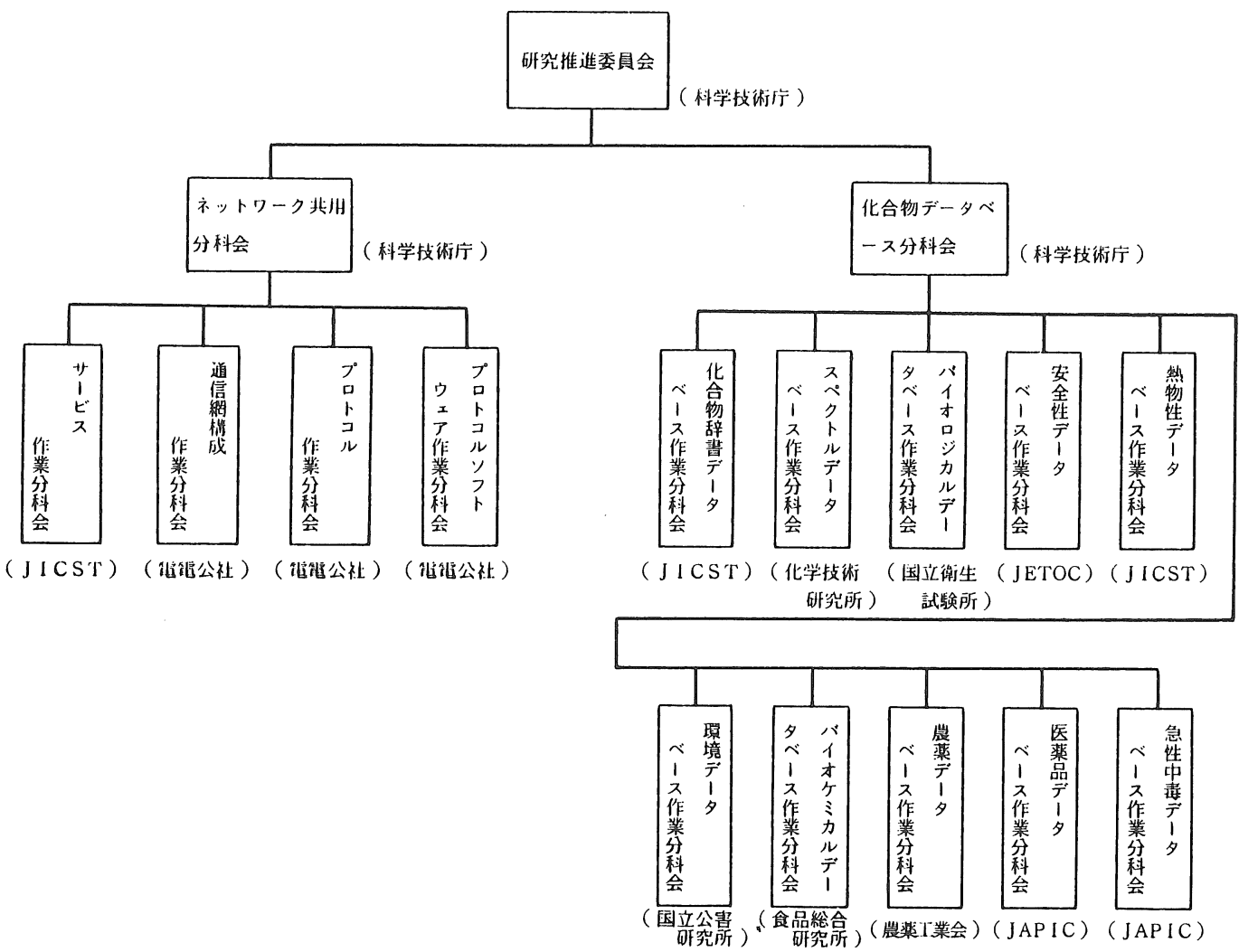

図 1 研究推進体制

ンラインネットワークシステムが定成した時点で システムを共用するために付けられる全体システ 么物質番号。

(口)物質名

和名（3 種類まで）と英名（2種類まで）が登録 されている。

(决化学式等

化学式, 分子量, 示性式执び構造情報の 4 種類 が入力されている。構造式については，図 1 の中 の日本語辞書データベースから出力される予定で あるので，それを利用する。

(二)物性データ

比重, 沸点, 融点, 溶解度, 分解性, 濃縮性を数 值情報として登録。

(小)環境媒体と分析法

大気, 水, 土壤, 底質, 人体 (臓器名等を表示), 動物 (名称を明記), 植物 (名称を明記) を対象と した場合の分析法を入力。ただしすべての媒体に ついてデータが入力されているわけではない。分 析法には, 前処理法, 測定機器, 測定条件, 使用 器具と試薬, 検出限界, コメント, 文献等が含ま
れている。

(へ)工業情報

用途, 生産量, 使用量, 現存量, 商品名等が入力 されている。

(ト)測定結果

大気，水，底質，生物試料についての分析結果を 入力。その内訳は測定年度, 試料の詳細, 試料数, 測定値 (測定回数, 平均值, 最高值, 最低值), 検 出限界值，コメントである。

これらの内容は現在, 国立公害研究所の大型電算機 の磁気ディスク内に格納されており，オンラインで随 時，検索できるようになっている。検索システムは大 型電算機がもっている既存のソフトウェアのひとつを そのまま利用している。次に検索で使用できるキー ワードを記載する。(1)整理番号 (2)分類番号 (3)物質 名（和名执よび英名）（4)分子量 (5)構造情報（現在の ところ, 八ロゲン化合物, 芳香族化合物, 脂肪族炭化 水素, メチル基を有する化合物, 含窒素化合物, 含イ オウ化合物, 含酸素化合物の 7 種類に分類） (6)溶解度 (7)分解性 (8)用途 (9)環境媒体 (10)抽出法 (11)前処理 法 (12)測定方法 (13)測定条件 (14)分析法の原典 (15)分 
析法の開発者とその所属機関。

検索は端末機より会話方式で，上述のキーワードを 順次入力することにより，相当する化学物質の数が ディスプレイ上に表示される。適当な段階で必要な情 報を指示すると, データの内容が出力される。以下に 検索例を示す。

〔例 1]クメン(和名)といら化学物質に関する全情報 を知りたい場合，キーワードとして「ワメイ：クメン」 と入力すると，ディスプレイ上に 1 件あることが表示 される。全内容を出力するよらに指示すると, 図 2 の ような情報が出力された。

〔例 2〕ガスクロマトグラフ（検出器, ECD）で環境 試料を分析したところ, 強いピークが観測され，マス スペクトルより分子量 $362 て ゙$ 多数の塩素原子を含むこ とがわかったので，执そらく農薬であろらと予想され た。そこでキーワードとしてまず「ブンシリョウ： 362-374」を入力し, 次に構造情報のキーワード「フ ラグメント：ハロゲン」を入力し, 最後に用途のキー ワードとして「ヨウト：ノウヤク」を入力すると，ディ スプレイ上に該当する物質が 1 件存在すると表示され た。化合物名（和名）を指示することにより，この物 質がアルドリンであることがわかった。

出力例の詳細は文献尚を参照されたい。

このシステムではデータベース中の文字列あるいは レンジを検索しているので，キーワードをらまく選ば ないと，該当件数が多くなってしまう。そのような場 合には複数のキーワードを結合させて，該当件数を少 なくすることが大切である。例えば，キーワードとし て“液々抽出”を選ぶと該当件数は266件，また“メチ ル基” (構造情報) を選ぶと，183件が検索されてくる ことになり,さらに別のキーワードを結合させないと 実用的ではない。

\section{3.マススペクトル検索システム}

環境中に存在する微量の有機物質を同定する有力な 手段のひとつにガスクロマトグラフィ一質量分析法が ある。マススペクトルは物質に固有のパターンを示す ため，物質の指紋としての役割をはたしている。マス スペクトルが物質の構造を反映していることは確かで あるが, 理論的にフラグメンテーションを解析できる 場合はそれほど多くなく，乙かも十分な経験を有する 研究者に限られているのが現状である。普通の人がマ ススペクトルから物質を同定するには，測定したマス スペクトルをデータ集の標準スペクトルと比較するの が一般的である。この場合, 標準スペクトルがどれだ け豊富に収積されているかといら点が重要である。い くつかの機関で, 以前からマススペクトルの収集が続
けられて括り，すでに数万に及ぶデータがまとめられ ている ${ }^{4,5)}$ 。ただ収集されたマススペクトルの信頼性に ついては必ずしも満足できるものではない。膨大な数 のマススペクトルをデータ集の形で出版することはい ろいろな点で困難になりつつあり, 今後は磁気テープ の形でューザーに供給されると予想される。また測定 された末知スペクトルが混合スペクトルであったり, 分子量や構造の情報が得られない場合には，同定がひ じょらに困難になる。これらの点に対処するにはコン ピューターによる検索が威力を発揮する。複雑なパ ターンを比較する事が必要なので, 高度なソフトウェ アの開発が重要になってくる。すでにいくつかの検索 手法が提案され, 害用に供されているものもある。 PEAK 法6) Hellerによって開発された手法で, 会話 形式で未知スペクトルのピークを1本づつ入力してい くものである。ピークが入力されるたびに，該当する レファレンススペクトルの数が表示され, 少数のレ ファレンススペクトルにしばられた時, 物質名を出力 させる。この手法は従来の文字情報の検索と同じ概念 の応用であるため, マススペクトルをパターンとして 把握していないし，時間がかかる。また検索されてき たスペクトルと末知スペクトルの一致している程度を 表現できない欠点がある。

Similarity Index 法7)は Biemann らによって開発さ れた手法でマススペクトルを14マス単位毎に区切っ て，その中で強度の大きなピークを 2 本選んで縮少ス ペクトルを作製し, 次式に従って SI 值 (Similarity Index）を求める。両者が完全に一致すればSI值は 1.00 となるので, 高いSI 值を与えるレファレンスが求 める化合物である可能性が大きい。

$$
\begin{gathered}
S I=\frac{\sum w\left\langle I_{j}^{\mathrm{U}} / I_{j}^{\mathrm{R}}\right\rangle / \sum w}{\sum_{k} \mathrm{I}_{k}^{\mathrm{U}}+\sum_{k} \mathrm{I}_{k}^{\mathrm{R}}} \\
1+\frac{1}{\sum_{i} \mathrm{I}_{i}^{\mathrm{U}}+\sum_{i} \mathrm{I}_{i}^{\mathrm{R}}} \\
\text { ただし } \\
\mathrm{W}=1.0 \quad \mathrm{I}<1.0 \% \\
\mathrm{~W}=4.0 \quad 1.0 \leqq \mathrm{I} \leqq 10.0 \% \\
\mathrm{~W}=12.0 \quad \mathrm{I}>10.0 \%
\end{gathered}
$$

ここで $I$ はピーク強度, wは重み。添字の $U, R, i$, $j, k$ はサンプルスペクトル, レファレンススペクトル, 全ピーク，一致したピーク，一致しないピークを表わ している。この方法はかなり良い結果を示し, 多くの ユーザーに利用されている。しかしスペクトルの質が 低い場合や塩素などを含む化合物で同位体ピークが多 く現われる場合には,検索結果の信頼性が低下するし， 
概念)。次式によって, 同定の結果の確からしさが計算 される。

$$
\begin{gathered}
K=\sum_{i}^{k}\left(U_{i}^{\mathrm{R}}+A_{i}{ }^{\mathrm{R}}+W_{i}-D\right)-W_{i} \\
C \%=\frac{\sum_{i}^{h} 2^{\mathrm{A}^{\mathrm{r}}} \cdot \sum_{i}^{k^{\prime}}\left(2^{\mathrm{A}^{\mathrm{l}}}-2^{\mathrm{A}_{i}^{\mathrm{k}}}\right)}{\sum_{i}^{j} 2^{A_{i}^{\mathrm{l}}}}
\end{gathered}
$$

ここでKはサンプルスペクトルがレファレンススペ クトルであることの確からしさを，C\%はそのレファ レンススペクトル以外のスペクトルの混ざり具合を意 味する。 $U, A, W, D$ は各々, $\mathrm{m} / \mathrm{z}$ にピークが出現 する確率に係る值, ピーク強度の累積出現頻度に係る 值, Window 因子, 希釈因子のことである。添字のU, $R, h, k, k$ 'は各々, サンプルスペクトル, レファ レンススペクトル，レファレンススペクトルにない ピーク, 一致したピーク, 許容幅以上の強度をもつピー クを表わしている。この PBM 法は末知スペクトル中 にレファレンススペクトルが含まれているかどらかを 調べるものであるから，混合スペクトルの場合でも副 成分が微量の時には同定が可能である。

今まで述べてきた方法は，末知スペクトルをレファ レンススペクトルの各々と比較していくのであるか ら, レファレンススペクトルの数が増えれば, 検索に はかなりの時間が必要となってくる。時間を短縮する には,レファレンススペクトルの数を大きくへらすか, 適当なフィルター（以下プリサーチと呼ぶ）をかけね ばならない。環境中で検出される化学物質は膨大な数 にのぼると予想されるので, レファレンススペクトル の数をへらすことは目的と合わない。またプリサーチ について十分な考慮を払った検索手法は今まで報告さ れていない。さらに環境試料中には多種類で微量の成 分が含まれているため, GC／MSでも質の低いスペク トルや混合スペクトルしか得られない場合もあり, こ れらのスペクトルに対しては新しい検索手法が必要と なる。マススペクトルの測定から同定までの作業を省 力化し, かつルーチン化することも重要であり, 今後 $\mathrm{GC} / \mathrm{MS}$ のミニコンピューターと大型電算機をオン ラインで結んで検索することが望まれる。これらの点 を考慮して著者らは新しい検索手法とオンラインシス テムの開発に成功したので, 次にその概要を紹介する。

NIES-MSLS (National Institute for Environmental Studies-Mass Spectral Library Search) シ ステムと呼ぶこのシステムでは，質の低いスペクトル や混合スペクトルに対しても精度よく検索を行ならこ とができ，オフラインであるいは質量分析計のミニコ
ンピューターとのオンラインでも実行できる。検索手 法はプリサーチとメインサーチから成っており, 検索 速度と信頼性は十分に実用的である ${ }^{9,10)}$ 。検索にかける スペクトルのことを以下，未知スペクトルと呼ぶが, この未知スペクトルが単一スペクトルの場合と混合ス ペクトルの場合が考えられ，混合スペクトルの場合に は主成分と副成分が同定されるようになっている。プ リサーチでは，不合理なレファレンススペクトルを除 去していき，メインサーチにかけるスペクトル数を出 来るだけ少なくしている。プリサーチは次に説明する 7 段階から構成されて抢り，順番に実施されていく。

(1)未知スペクトルの最大質量ピークとベースピーク から，検索を行ならべき分子量範囲を決定する。ただ し, パラメーターの入力により, ユーザーの希望する 分子量範囲を指定することもできる。

(2)末知スペクトル中の最大質量ピークの質量数より 大きい質量数に一定強度以上のピークを有するレファ レンススペクトルを除外する。

(3)未知スペクトルとレファレンススペクトルのベー スピークが一致していなければならない。

(4)レファレンススペクトルで分子イオンが出現して いる場合は, 未知スペクトル中にも同一質量数にピー クが存在しなければならない。

(5)分子量より 4 質量単位低い質量数から11質量単位 低い質量数の範囲に，末知スペクトルは強度 $5 \%$ 以上 のピークを有してはならない。この条件は塩素, 臭素, イオウ, ケイ素原子のいうれも含まない化合物のレ ファレンススペクトルに対して適用される。混合スペ クトルはこのチェックを受けないで次の(6)のステップ に進さ。

(6)レファレンススペクトルに拈いて, 分子イオンか ら偶数質量のフラグメントが脱離したイオンで強度 $20 \%$ 以上ピークは未知スペクトル中にも必ず存在し なければならない。これは主として転位イオンピーク や逆 Diels-Alder 反応によるイオンのピークの有無を チェックする目的で設定されている。例えば，次のよ らな場合である。<smiles>[CH2+]CC(C)(C)ONC(C)CCC</smiles><smiles>C=CCCC(O)=CC(CC)CCC</smiles> 
アミン類など含窒素化合物では十分に機能しない場合 もある。

(7)塩素, 臭素, イオウ, ケイ素原子のいづれかひと つでも含さレファレンススペクトルが最高質量部分に 2 質量単位おきの同位体パターンを示している場合に は，末知スペクトルも同じパターンを示さなければな らない。

以上のプリササーチにより, 約 3 万あ屯りのレファ レンススペクトルがわずかの数にしばられる。その時 の様子を表 1 に示す。

プリサーチを通過したレファレンススペクトルが次 のメインサーチにかけられる。メインサーチでは，末 知スペクトルがあるレファレンススペクトルであるこ との確からしさを算出するものである。次式によって 2 種類のパラメーターが計算される。

$$
\begin{aligned}
K S & =\sum_{j}^{k}\left(U_{j}^{\mathrm{R}}+A_{j}^{\mathrm{R}}\right) / \sum_{i}^{1 \overline{5}}\left(U_{j}^{\mathrm{R}}+A_{j}{ }^{\mathrm{R}}\right) \\
P C & =\left\{\sum_{j}^{h} I_{j}{ }^{\mathrm{U}}+\sum_{j}^{k^{\cdot}}\left(I_{j}{ }^{\mathrm{U}}-\alpha_{j} I_{j}^{\mathrm{R}} \rho \min \right)\right\} / \sum_{j}^{h+k} I_{j}{ }^{\mathrm{U}} ; \\
\rho & =I^{\mathrm{U}} / I^{\mathrm{R}}
\end{aligned}
$$

ここで, $K S$ は未知スペクトルがレファレンススペク トルであることの確からしさ (信頼度)， $P C$ は末知ス ペクトル中に拈ける，レファレンススペクトル以外の スペクトルの混入の程度 (不純度) を意味する。それ 以外の記号はPBM 法の場合と同じ内容を意味する。 ただし， $\alpha$ はピーク強度の許容変動幅を決める経験的 パラメーターである。

このメインサーチではレファレンススペクトル中の 15本のピークだけが使用される。その際，選ばれる 15 本のピークはKSORT(後述) が15までのピークであ る。オリジナルピーク数が 15 本以下の場合は全ピーク が選ばれる。メインサーチの基本的な考方方はPBM 法に類似した部分もあるが，混合スペクトルの検索を しやすくするために，Window の考え方を $P C$ の算出 に取り入れ，KSの計算では除いている。つまり PBM 法ではピーク強度の変動が信頼度と不純度に直接, 反 映するが, NIES 法では不純度にはきいてくるが, 信頼 度には何の影響も与えない。ただ，類似したレファレ ンススペクトルが多くある場合には，この手法だけでは 正解が求来りにくく, 捕捉的に計算された SI 值(前述) を参考にして判断する。混合スペクトルでは $P C$ 值が 高くなるので, 逆に検索結果で $K S, P C$ 值が共に高い 值を示していれば，混合スペクトルである可能性を考 慮しなければならない。

混合スペクトルに拈いて，第 2 成分（副成分）を同 定するためには次のように行なら。まず，次式に従っ

\begin{tabular}{|c|c|c|c|c|c|c|}
\hline \multirow[b]{2}{*}{ 化 合 物 } & \multicolumn{6}{|c|}{ プリサーチに拈けるステップ } \\
\hline & 第 1 & 第 2 & 第 3 & 第 5 & 第 6 & 第 7 \\
\hline ドュサン & 32597 & 26337 & 877 & 327 & 248 & 248 \\
\hline 2-メチルナフタレン & 17399 & 3458 & 32 & 18 & 18 & 12 \\
\hline ミルセン & 20501 & 6788 & 102 & 27 & 26 & 26 \\
\hline 3ーメチルブタノール & 5224 & 649 & 39 & 33 & 33 & 33 \\
\hline メントール & 18462 & 4699 & 88 & 35 & 27 & 27 \\
\hline 酸化メシチル & 12767 & 2366 & 49 & 32 & 32 & 31 \\
\hline 吉 草 酸 & 9977 & 1640 & 12 & 4 & 4 & 4 \\
\hline カプロン酸 & 13269 & 2868 & 18 & 8 & 7 & 7 \\
\hline フェニル酢酸 & 18428 & 4685 & 117 & 52 & 52 & 49 \\
\hline 酪酸エチル & 17265 & 4485 & 129 & 59 & 59 & 59 \\
\hline ステアリン酸エチル & 9527 & 3094 & 21 & 16 & 16 & 16 \\
\hline 酢酸ベンジル & 19091 & 5068 & 27 & 13 & 13 & 13 \\
\hline 安息香酸ブチル & 21436 & 7856 & 48 & 10 & 10 & 8 \\
\hline アニリン & 11268 & 1611 & 12 & 6 & 6 & 6 \\
\hline インドール & 15357 & 2485 & 20 & 9 & 9 & 9 \\
\hline キノリン & 16641 & 2988 & 17 & 10 & 10 & 9 \\
\hline
\end{tabular}

表一1 NIES-MSLS システムにおいて, プリサーチの各 ステップを通過したレファレンススペクトル数

注）これは今回報告したシステムの前のシステムによる結果で あるため, プリサーチの第 4 ステップは含まれていない。ま たこの時のレファレンススペクトルの総数は33898であっ た。

て, $I_{j}^{U}$ を求め, 次に最大の $I_{j}^{D}$ 值を 1000 として規格化を 行ない，差スペクトルを求める。

$$
I_{j}^{D}=I_{j}^{D}-\beta \cdot I_{j}^{R}
$$

ここで $\beta$ は第 1 成分(主成分)の混入割合で，ユーザー が指定してもよいが，普通はコンピューターが自動的 に設定する。 $\beta$ の算出法は次の 2 種類のいづれかによ る。(1)レファレンススペクトルと末知スペクトルか ら, 最小自乗法により求める。(2)前述の $\rho \min を \beta$ の值とする。いつれの場合も $0.5 \leqq \beta \leqq 1.5$ 。求められた 差スペクトルを前と同様のプリサーチ, メインサーチ にかけて第 2 成分を同定する。第 1 成分, 第 2 成分を 別々に同定することもできるし，同時に同定すること もできる。差スペクトルの計算では, レファレンスス ペクトル中のオリジナルピーク（最大 100 本まで）がす ベて使用される。

末知スペクトルのデータ入力はカードによるバッチ 方式あるいは電話回線を介しての端末機による TSS 方式で行なわれる。現在使用中の大型電算機 (HITAC M-180）に打ける検索速度は, 未然スペクトルの内容 によって若干異なるが，10ケの未知スペクトルについ て約 1 分足らずであり，実用的には十分である。

次にこの NIES-MSLS システムによる検索結果に ついて述べる。単一スペクトルの場合, 正解率は約 $80 \%$ 
程度であり，不正解の場合の約半数はレファレンスス ペクトルの異常によるものであった。残りの不正解に ついては，類似スペクトルが多いために，検索で上位 にランクされなかったためである。これについては現 在，手法の改良を進めているので，近い中にかなりの 程度まで改善される。混合スペクトルの場合, 第 1 成 分, 第 2 成分ともに正解の割合は約 $50 \%$ 程度であった。 不正解の原因のかなりの部分は，単一スペクトルの場 合と同様, レファレンススペクトルが不良であること による。混合スペクトルでは，第 2 成分の検索に限界 のあることがわかった。まとめてみると次のような場 合に検索が困難になる。(1)第 1 成分之第 2 成分のマ ススペクトルがきわめてよく似ている場合。(2)第 2 成分の混入割合がひじょうに小さい場合。いづれの場 合も，求められた差スペクトルが，本来示すはずの第 2 成分のスペクトルパターンとはかなり異なってしま 5 。

\section{4.マススペクトルデータベースシステム}

次にNIES-MSLS システムのためのデータベース について述べる。データの更新が容易に行なえるよう にとの観点から，VSAM ファイル（仮想記憶アクセス 法）を用いて，スペクトルデータファイルと化合物名 ファイルを作製した。さらにこのファイルのインバー テッドファイルである分子量ファイルも作られてい る。データの内容は次のと扣りである。ここで*印の 付いた項目はコンピューターが入力データから計算し てくれる付加情報であるので，＊印のない項目のみを 入力する。

(1) レコードキー*

6 バイトからなる16進12桁の化合物認識番号で, 分子式から一義的に決められる。

(2) 化合物名称

正式名, 慣用名, 略号など複数個の名称が, 全体 で200文字以内で入力。

(3) 分子式

水素からウラニウムをでの, 同位体を含む全元素 記号が使用可能。

(4) CAS 登録番号

既存物質についてはChemical Abstracts Index で調べ，新物質については“U”を入力しておき，

CASに登録された時点で番号を入力する。また置 換位置の確定していない物質のスペクトルでは, “U”を入力する。

(5) 分子量*

分子式から整数分子量と精密分子量を計算する。

(6) 保持指標
GC に拉ける保持指標が 5 種類をで入力できる。 不明の場合は“U”を入力。

(7) コメント

測定機種, 測定機関，特記事項などを入力する。

(8) スペクトルデータ

ピークの質量数と相対強度（ベースピークを1000 として規格化した值)。相対強度 10 以上のピークを 対象として, 800本まで入力できるが，データベー スには最大 100 本までのピークが登録される。100 本のピークの選択は後述の KSORTによって決 められる。ベースピークを含まないスペクトル データは受け付けない。

(9) U 值*

ある質量数にピークが出現する確率から計算され る値。

(10) A 值*

ピークがある相対強度を有する確率（累積出現頻 度）から計算される值。

(11) $\mathrm{KSORT}^{*}$

各ピークについて $K=U+A+C$ で, $K$ 值を計算 して，K值の大きな順に並べた時の順位。ここで $C$ は特異な定数で, ベースピーク, 分子イオン, 転位ピーク, 中性欠損ピークには 100 , 強度 20 以上 のピークには 30 , それ以外のピークには 0 とする。

(12) $K 15^{*}$

KSORTが15のピークと同じK 值をもつピーク の中の最大 KSORT 值 $(\leqq 100)$ 。

(13) $\mathrm{NPK} 2^{*}$

強度 20 以上のピーク本数。

(14) $\mathrm{NPK}^{*}$

全ピーク本数。

(15) $\mathrm{BP}^{*}$

ベースピークの質量数。 3 本以上ある時は高質量 側から 2 本をとる。

(16) $\mathrm{MME}^{*}$

各化合物に許容される最大質量数で, 次式で計算 される。 $\mathrm{MME}=$ 分子量十 (塩素原子の数 $) \times 2+$ (臭素原子の数) $\times 2+$ (ケイ素原子の数 $)+($ イ ウ原子の数) +3 。

(17) ISNM*

分子中の塩素, 臭素, ケイ素, イオウの原子数。

(18) NIS*

$\mathrm{Cl}, \mathrm{Br}, \mathrm{Si}, \mathrm{S}$ を含む化合物で，最大質量部分に 2 質量単位おきの同位体ピークが現われている場 合, その本数。

(19) ISOTOP*

NIS が 0 以外の時, 同位体ピークの最大質量 
(20) $\mathrm{ISOPK}^{*}$

最大強度の同位体ピークの強度を 1.0 とした時の 同位体ピークの強度比（最大 5 本まで）。

(21) NEO*

相対強度 200 以上で, 分子量から偶数質量をさし引 いた質量数のピーク本数。

(22) EVODM*

$\mathrm{NEO}$ で取り上げたピークの $\mathrm{m} / \mathrm{z}$ 值(最大 10 本)。

(23) EVODI* $^{*}$

EVODM に対応する相対強度

(24)ILIM*

分子最51以上で，かつ $\mathrm{H}, \mathrm{C}, \mathrm{N}, \mathrm{O}, \mathrm{F}, \mathrm{Si}, \mathrm{P}$,

$\mathrm{S}, \mathrm{Cl}, \mathrm{Br}, \mathrm{I}$ 以外の元素を含まない化合物の場合 は ILIM $=$ MME -12 ，その他の場合は 0 。

(25) MOLION*

相対強度50以上の分子イオン（同位体ピークを含 む時はその最大強度のピーク）が観察される場合 はその $\mathrm{m} / \mathrm{z}$ 值。それ以外は 0 。

このデータベースの更新はTSS 端末から会話方式 で行なわれ, データの追加, 削除, 一部修正が実行さ れる。修正できる項目は人力データのすべての項目で あり,スペクトルデータの場合はピークの追加, 削除, 一部修正, 全ピークの修正(置換)がでさる。さらにデー タベースの内容を自由に検索, 出力できる。検索に使 えるキーワードは, レコードキー, 化合物名, 分子量, 分子式, CAS 登録番号である。これらのキーワードに よる出力例は報告書3を参照されたい。

データベースを構築する際, 考慮しなければならな い点がいくつかある。今回のデータベースに入力した データは $\mathrm{EPA} / \mathrm{NIH}$ のオリジナルデータ（約 38,000 スペクトルが収録された磁気テープをリース契約で借 用）と国立公害研究所で測定した標準スペクトル（約 300件)であるが，膨大なメモリーが必要であった。今 後さらにデータが増加していくことを考光ると, この 種のデータベースを各研究機関が所有することはかな りの困難を伴らと予想され, 国家的な事業として行な われることが望ましい。もらひとつの問題点として, この種のデータベースを公共の利用に供するために は，登録データが自前のものでなければならず，現在 の我国ではこの点で他国よりかなり遅机ているように 思われる。さらにマススペクトルの質を評価する手法 が早急に確立される必要がある。

\section{5.おわりに}

ここでは著者らが開発してきた 2 種類のデータべー スと検索システムについて紹介してきた。これらのシ ステムが実用に供され，期待された成果が発揮される
ためには，データベースに入力されるデータの量質と もに十分でなければならない。個々の機関でデータ集 積を行ならことはひじょらに非能率的であり，セン ターの役割をはたす機関が必要である。

な拉，この研究の中で，環境化学物質のデータベー スについてはいくつかの地方公害研究所と環境庁保健 調査室の方々との共同研究であり，マススペクトル データベースについては国立公害研究所の新藤純子 氏，伊藤裕康氏との共同研究である。

（原稿受理 昭和58年12月 5 日）

\section{引用文 献}

1) Heller, S.R. and Milne, G.W.A. (1979) The NIHEPA chemical information system, Environ. Sci. Technol. 13, 798-803.

2) Milne, G.W.A., Heller, S.R., Heller, R.S. and Martinsen, D.P. (1980) The NIH/EPA chemical information system, Adv. Mass Spectrom. 8B, $1578-1581$.

3 ）化合物環境データベース作業分科会（1983）化合 物環境データベース作成・検索システムに関する詳 細設計, 国立公害研究所出版物 $(\mathrm{N}-57-10)$.

4 ) 日本質量分析学会 (1980) 物性データ調査研究報 告, 質量分析データ 第 2 巻, 科学技術庁振興局.

5 ) Hohn, M.E., Humberston, M.J. and Eglinton, G. (1977) Storage and retrieval of mass spectral information, Pure Appl. Chem. 49, 1817-1825.

6 ) Heller, S.R. (1972) Conversational mass spectral retrieval system and its use as aid in structure determination, Anal. Chem. 44, 1951-1961.

7 ) Hertz, H.S., Hites, R.A. and Biemann, K. (1971) Identification of mass spectra by computer-searching a file of known spectra, Anal. Chem. 43, 681 -691 .

8 ) Pesyna, G.M., Venkataraghavan, R., Dayringer, H.E. and McLafferty, F.W. (1976) Probability based matching system using a large collection of reference mass spectra, Anal. Chem. 48, 1362 $-1368$.

9 ) Shindo, J., Yasuhara, A., Ito, H. and Mizoguchi, T. (1982) A new library search system for the identification of mass spectra, Chem. Lett. 521 -524 .

10) Yasuhara, A., Shindo, J., Ito, H. and Mizoguchi, T. (1983) Identification of multicomponents in mixed mass spectra by library search system, Comput. Enhanced Spectrosc. 1, 117-123. 